\title{
Crafting an International Legal Regime for Worker Rights: Assessing the Literature since the 1999 Seattle WTO Protests
}

\author{
John D. French and Kristin Wintersteen \\ Duke University
}

Since the fall of the Soviet Union in 1991, critical attention has increasingly focused on the remaining world system, capitalist in nature and anchored in the World Trade Organization (WTO), founded in 1994 as the successor to the 1948 General Agreement on Tariffs and Trade (GATT). As the 1990s progressed, a smattering of exciting new intellectual work began to appear on the social and environmental impacts of the international trade and investment regime, especially given its apparently negative impact on many developing countries and the world's working people. "The distinction somewhat comfortably maintained by 'trade hands' who managed the post-World War II international economy-that trade is strictly a commercial function with no immediate connection to social concerns-has evaporated under the pressure of political and social forces generated by the globalization of the economy." 1

These incipient currents of political disquiet, at first easily overlooked, would surface with surprising force in late 1999 when large and dramatic street protests confronted the WTO's Third Ministerial Conference in Seattle. For the first time, a meeting of the mandarins of international trade was met with a massive and unruly expression of democracy in the streets. The Seattle events seized the world's imagination in part because they were so unexpected in a thriving tradebased US city that was, at the time, the world headquarters of Boeing and Microsoft, giants of the "old" and "new" global economy, respectively. The labor issue even reverberated in the suites of the city, as government representatives debated the inclusion of worker rights in the agenda of the "Millennium Round" of international trade negotiations that was to have started in Seattle. ${ }^{2}$

The Seattle protests heightened public and scholarly attention to proposals for social or worker rights clauses in international trade agreements, an issue that had briefly flared up at the 1994 GATT meeting in Marrakesh (though not in the streets). As the new millennium began, the labor question was part of a vital international policy debate that spoke to societal concerns felt well beyond the usual haunts of academic labor specialists. Indeed, the formation of the WTO, with near-universal membership, led a number of labor scholars, as early as 1996, to envisage new possibilities for promoting worker rights on a world scale. ${ }^{3}$ Drawing on interdisciplinary reflections going back to the early twentieth century, this review essay offers a point of entry into the pitched debates about globalization, which peaked during the protest cycle 
from 1999-2003 and impressed upon public opinion that our current problems are fundamentally intermestic (international and domestic) in nature. As has recently been observed, "intermestic problems demand intermestic as well as domestic solutions, and the challenge ... is to integrate these very different praxes in response to the ever-deepening integration of the domestic, the transnational, and the international." 4

To understand the fight to shape the capitalist world that trade has built since the Second World War, it is necessary to focus on the social dimension of the international trade and investment regime: the link between trade flows, national and social welfare, and issues of equity at both the international and domestic levels. It is preeminently an intermestic approach that points towards possible alternatives to some of the most unsettling aspects of today's world. As a prescient World Bank report noted in 1995, "inequality, both across regions and within countries remains a significant feature in the global economy. By one estimate, in 1870 the average income per capita of the richest countries was eleven times that of the poorest; that ratio rose to thirty-eight in 1960 and to fifty-two in 1985." The world economy has thus been characterized by "a pattern of rising prosperity, unequally shared" between nations and within them. ${ }^{5}$

To better grasp the stakes in the debate about globalization and labor requires a broader understanding of the historical political economy approach to trade exemplified by Steven Sanderson's excellent 1992 study, The Politics of Trade in Latin American Development. While criticizing those "free trade" ideologues who isolate trade from history, society, politics, and morality, Sanderson offered a balanced understanding of international trade as neither bête noire nor salvation. Above all, he called attention to the fact that history demonstrates that even "under the best conditions ... the gains from trade ... have accrued unevenly, provoking political conflict at the international level"-between the North and South at times, but most often between powerful rival trading countries or blocks. In addition, trade has provoked political conflict at the domestic level in the form of disputes "over the distribution of the gains from trade (or no trade) for development."6

If we are not to be willfully naive, Sanderson notes, then we must recognize that the international capitalist trading regime "was [and is] plainly designed for winners" without paying much attention to "the losers in the allocation of economic values in the system." In this regard, the World Bank deserves credit for the intellectual honesty with which it recognized, in 1995, that "free trade produces losers as well as winners," both within countries and between them. ${ }^{8}$ Under such conditions of unequal development and compounded advantage, the current game of capitalist globalization operates as a form of winner-take-all that further centralizes wealth and power in a changing but deeply unequal world system.

After a brief review of the evolving international debate, this essay concentrates on recent books that grapple with proposals to incorporate worker rights and/or labor standards into the structure of the international trade and 
investment regime. From there, it will take up two recent books that explore international regulatory dynamics in international maritime shipping, a key but little-known sector of our globalized world economy. The essay then moves on to discuss cross-border labor solidarity campaigns, corporate codes of conduct, and trade-linked labor rights while considering how we might get there from here, as a step toward a more just and post-neoliberal world.

\section{International Regulation of the Conditions of Labor? The Evolution} of the Literature, 1919-2005

Twentieth century scholarly interest in formulating an international legal regime of labor standards and worker rights first originated as a challenge to laissez faire economic thought and was directly linked to the founding of the International Labor Organization (ILO) in the 1919 Treaty of Versailles. Although the British Labour party published a Memoranda on International Labour Legislation in 1919, economist Herbert Feis was the first to publish an intellectually substantive piece in 1927 under the title "International Labour Legislation in the Light of Economic Theory." 9 The heterodox nature of his proposition was underlined by the editor of the ILO's International Labour Review, who noted that many did not agree that "the regulation of labour conditions by international action is either legitimate or desirable ... [given] the conclusions of the 'classical' economic theory." It is unclear, the ILR editor went on, whether it is possible to reconcile "the two conflicting points of view - the one holding that international competition is the essential lever for raising each country to its highest level of prosperity, the other that international competition depresses labor conditions and creates hardships which can only be remedied by international action."10

When Feis wrote in 1927, the question of labor and the international was secondary to the heart of the struggle of those decades: the establishment of national legal regimes of protective labor standards and legal rights to collective bargaining. Under these conditions, it is not surprising that the labor-trade link failed to gain a sustained place in intellectual debates over the following half century. Indeed, an exhaustive survey by French makes the trajectory of scholarly interest clear.

It was only after the geopolitical and ideological transformations of 19891991, which came to be called "globalization" by the turn of the millennium, that

TABLE OnE: Scholarly Articles and Books on the Labor-Trade Link

\begin{tabular}{lrc}
\hline Years & \# of published items & Rate of publication \\
\hline $1919-1979$ & 42 & 0.7 per year \\
$1980-1989$ & 51 & 5.7 per year \\
$1990-1999$ & 362 & 40.2 per year \\
$2000-2005$ & 214 & 42.8 per year
\end{tabular}


the labor-trade link became central to academic and policy debate. Since the 1999 Seattle protests catapulted the issue to the center of international politics and policy, we have seen an international and interdisciplinary publishing boom that includes articles across a wide range of countries, disciplinary fields, and thematic and topical specializations. Most impressively, the post-Seattle years have seen the appearance of ten edited collections touching on labor and trade, as well as six monographs or policy briefs on the international labor standards and trade debate and a number of highly technical studies on data gathering.

The world of work at the international level, unfortunately, does not generate the mass of empirical and statistical data that characterizes the well-funded world of business. It is perhaps not surprising that the available information sources, sporadically generated by poorly funded entities, fall short of capturing the dynamics of the world of work across our heterogeneous but integrated global economy. This is clear from the multi-volume reports issued in 2003-2004 by the Committee on Monitoring International Labor Standards of the US National Research Council (NRC). ${ }^{11}$ The main NRC volume systematizes current sources of data from governmental, non-governmental (NGO), and international institutions and organizations as they bear on the four "core" standards designated by the ILO in 1998 (freedom of association and right to collective bargaining, forced or compulsory labor, child labor, and discrimination), as well as the broader "acceptable conditions of work" included in legal definitions of "Internationally Recognized Worker Rights" (IRWR) established by US trade law in the 1980s.

"Not only are the sources of information often problematic," the NRC notes, "but there are ongoing controversies about the precise definitions" while efforts to "operationalize compliance" are far from "straightforward."12 A similar ambition inspired an ILO employee whose 2005 monograph likewise focuses on ILO "core" conventions, although they are placed within a more politically powerful language of "human rights," not "labor standards." In creating a worldwide country indicator measuring "fundamental rights in the world of work," W.R. Böhning notes many drawbacks: widely used indexes marred by geopolitical bias (e.g., Freedom House), the existence of at best "semi-scientific" estimates for bonded labor, and extrapolated figures for child labor based on imperfect samples with little ongoing checkup. ${ }^{13}$

Even a quick perusal suggests that the new scholarship lacks an historical depth of knowledge about what has been, since the Second World War, variously called international fair labor standards (IFLS), minimum international labor or social standards, IRWR, "international worker rights," "core" labor rights, "human rights at work," or a "social clause." The difficulties referenced by the NRC and Böhning were lamented by an earlier generation who saw "thorny problems of definition," the lack of "an international consensus," and "deficiencies in knowledge." Lamenting "the obscurity and confusion," they cited "numerous misunderstandings," "vague definitions," and the lack of "a unique and comprehensive set of definitions." 14 As a sympathetic US congressional staffer noted in 1987, one was left with the impression of a "long string of false starts, hollow promises, and forgotten laws." 15 
If lack of clarity long characterized international social clause advocacy, the malaise stemmed in part from its political marginality, which failed to attract powerful intellects, allies, or interest groups. During these years, northern unions were mostly disinterested given its doubtful effectiveness for protectionist ends compared to the use of their national political influence. ${ }^{16}$ Thinking about international labor rights before the 1980s was restricted mostly to those associated with the ILO and the US Department of Labor, ${ }^{17}$ and it was only in the mid-1980s that a US group of dedicated Third World labor solidarity activists brought the issue to prominence both nationally and internationally. A recently published doctoral dissertation by German political scientist Thomas Greven explores how activists and staff people from religious, human rights, solidarity, and trade union organizations transformed an informal working group into the International Labor Rights Education and Research Fund in 1986 and made history. The effort was spearheaded by a Methodist minister, Pharis Harvey, who had been involved with anti-dictatorial struggles in South Korea. The initial success achieved by these leftwing policy entrepreneurs stemmed from the cooperation of Democratic Congressman Don Pease, himself a free trader with a labor base in Ohio, according to Greven's interviewees. Pease had sufficient clout in a Democratic-controlled Congress to insert IRWR clauses, with provision for sanctions, in a sequence of US trade and investment laws in the 1980 s, developments that prompted the first sustained wave of academic work on the labor-trade nexus. ${ }^{18}$

Drawing on extensive interviews and contemporary primary sources, Greven carries the story from the heated years of US intervention in Central America through the public controversies over NAFTA to the eve of Seattle. ${ }^{19}$ For those of us who participated in the activism of this period, Graven provides up-close answers to questions of interest. He also rightly notes that these efforts were neither the expression of a mass movement nor a project of US trade unionism as such. In fact, they were often in conflict with the AFL-CIO, while drawing support from some of its unions and their staffs. The long-term significance and impact of these initiatives-as Greven astutely notes - is to have made "international labor rights" one of "the three central pillars of [the] progressive globalization critique" in the United States, the other two being the environment and the reform of international financial institutions. He also offers an illuminating discussion of the conflicts between these self-consciously internationalist labor rights advocates in the 1990s and more powerful and established interest groups, especially trade unions whose actions were decisively important at the Seattle WTO protests yet still shaped, at times, by tactical calculations and protectionist reflexes. ${ }^{20}$

\section{World Views in Conflict: Economists versus Lawyers}

The current world-wide publishing boom on the labor-trade nexus marks a profound post-Seattle transition in the intellectual and political landscape. International labor rights in the 1980 s was of fundamental concern to marginal 
leftwing activists, while it plays a vital role today in the controversies over the model of neoliberal globalization, whose social and democratic deficits brought hundreds of thousands into the streets from 1999 through 2003. The stakes are made clear in the edited books under review where, for the most part, labor lawyers are pitted against economists on the wisdom of linking labor standards or rights to trade. The typical framing of the issue by economists, even when not militantly hostile like Jagdish Bhagwati, ${ }^{21}$ is to define the international labor standards debate as a subset of their central public justification of globalization: that it benefits the poor, especially in the "developing countries and the poor in those countries." 22

Neoliberal academics routinely rebut arguments by suggesting that their intellectual opponents are simple-minded believers in literal "race-to-the-bottom" or "pauper labor" scenarios. ${ }^{23}$ Yet globalization's intellectual critics have always linked a systemic tendency to downward pressure on wages, labor conditions, and acquired rights (flexibilization) to capital mobility-not trade-while illustrating its impacts through sectoral examples. As an example of this critical approach, the 2004 book by sociologist Robert J. S. Ross notes that the "availability of a global pool of cheap labor" has weakened workers' bargaining power and undermined "the higher standards of compensation and benefits in the older industrial regions." But, he goes on, this "global competition in manufacturing export" is no longer "only a North-South matter ... [C]ompetition today is as much South-South as it is North-South," especially with the rise of China's exports. ${ }^{24}$

Yet supporters of neoliberal globalization continue to falsely claim that their opponents believe absolute impoverishment is a necessary consequence, which they refute by citing across-the-board national outcomes. ${ }^{25}$ They continue these evasive tactics by suggesting that international labor standards simply will not make workers in the South substantially less poor or maintain jobs in the North, although these are not the rationale for current social clause proposals. They ostentatiously commiserate about the vast informal sector in developing countries whose conditions, they claim, would be aided by trade-fueled growth while looking askance at southern industrial wage earners. They thus issue dual warnings against high-jacking by protectionist northern interests and against the deepening of internal hierarchies within the South as a result of any improved wages and conditions for export-linked workers. On "the desirability of using trade sanctions for enforcing" labor rights, the burning question in the policy debate, "the answer is very clear to most economists. It is emphatically that it is not." 26

Overall, economists attack social clause advocacy through the abstract econometric modeling preferred by today's mathematically-enabled free market economists. For example, Stanford economist Robert Flanagan offers a particularly dubious test of the proposition "that trade suppresses labor conditions" by testing whether countries refuse to ratify ILO conventions (themselves toothless) in order to reduce costs and attract foreign direct investment. Finding little relation between ILO ratifications and labor conditions, he ends by denying the existence of even indirect processes by which 
"international markets [might] produce a degradation of labor conditions. The direct [statistical] tests of the effect of free trade on labor conditions reveal," he insists, that "free trade policies are associated with better, not worse, labor rights and conditions." 27

It is hardly surprising that mainstream economists, hostile to state regulatory initiatives, would be overwhelmingly opposed to "interference" with the liberal dogmas of free trade, whether conducted in the name of human rights or the general welfare (abstractions of which they are suspicious). Yet the hegemonic capacity of neoliberal ideals is not to be underestimated, especially during its triumphant high point in the 1990s (the pensée unique as it is called by the French, or neoliberal "globalization of the mind" in the words of Brian Langille). During the ideological flux after 1989-1991, neoliberalism proved capable of constituting itself as both a new common sense and a utopian future. We find this reflected in Labour Laws and Global Trade, a 2005 handbook by an emeritus English labor law professor of South African origin. Indeed, Bob Hepple opens his useful book by discussing the shift in his own views since the 1950s when he worked as a lawyer for the leftwing South African Congress of Trade Unions allied with the African National Congress. Disposed to favor international sanctions for good causes, he now opposes making "trade conditional upon observance of labour standards" (conditionality) and rejects sanctions for their violation. In both cases, he does so because of "the undoubted benefits of free trade in promoting economic growth, democracy, and improved labour standards." (He would allow sanctions in extreme cases for pariah states. $)^{28}$

Hepple's book offers a comprehensive survey of trade-labor legal links, including 100 technical pages on the case of the EU, while his text boxes offer succinct explications of terms, institutions, legal cases, and so on. Yet Hepple's vision of "transnational labour regulation" in the "new global economy" seems underwhelming in light of the problems he himself mentions. At one point, he describes his solution as a "spider's web of hard and soft transnational regulation [that] is being weaved around domestic laws and is profoundly influencing them." 29 Elsewhere, he calls for the implantation of an unspecified "transnational regulatory framework which encourages and develops the potential of TNCs [transnational corporations] to raise the labour standards of economically and socially disadvantaged groups of workers and producers, particularly in the informal sector [in the South]."30

While Hepple envisages himself as following "a path between extreme versions of free trade and protectionism," his Blairite Third Way is far closer to the "stereotypes and dogmas" of pro-globalization ideologues than to labor law professors in his earlier 2002 edited collection. ${ }^{31}$ In his introduction to Social and Labour Rights in a Global Context, Hepple had sounded a different note: "Social rights at international, regional, and national levels are increasingly seen as beacons of resistance against the disempowerment of local communities, trade unions, and other social organization which globalisation and neoliberalism entail." As he notes, "more than half the world's workers are still not 
covered by 'core' ILO conventions and even states which have ratified them fall a long way short of meeting their obligations." 32 Indeed, the book opens with the honoree Lord Wedderburn's passionate denunciation of the "depth of expropriation, poverty, and powerlessness among the world's workers in today's global economy, and [the] increasing relative poverty even in developed countries." For this emeritus labor law professor, "the widely acknowledged need for national and transnational core labour standards" stands as "the central issue of labor law" in the future. "After Seattle the world organisations dominated by global capital have more clearly become less part of the solution than part of the battleground.",33

Viewed with a jaundiced eye, Lord Wedderburn's philippic against the market principle, neoliberalism, and the failures of the EU (and its unions) could be seen as a backward-looking gesture by a man who is not resigned, as another lawyer puts it, to "the death of labor law." And there is strong evidence that an "erosion or collapse of the old certainties" in the labor law field has accompanied globalization, as can be seen in a 2002 edited collection entitled Labour Law in an Era of Globalization. If the nation state is in retreat, if not irrelevant, it is little wonder that the future of labor law would seem bleak to many in a globalizing world. After all, it has long been seen (incorrectly, they argue) as "growing out of a relatively unified, coherent, and nationally based legal regime." Moreover, it is routinely interpreted as "inextricably linked to a particular political project, roughly speaking, postwar social democracy. Consequently, labor law is thought to have "no purchase outside" those parameters in the face of "the monolithic imperative of free market globalization."34

The twenty-seven international contributors to Labour Law in an Era of Globalization hail the labor-law subfield as a "rare exception" in a legal profession that is largely "conservative and apologetic." Loosely linked to the US-based Critical Legal Studies movement, their volume directly engages with the law's “inescapable political dimension," thus taking up Lord Wedderburn's challenge. Unlike the trade fetish of economists, these progressive lawyers correctly attribute absolute causal centrality to the vastly enhanced mobility of capital. As Brian Langille notes, the move to "a model of deep economic integration," in which capital operates with the world as its stage but not labor, has occasioned a "radical realignment of political and economic realities." With the increased credibility of exit options by capital, this "deep integration fragments national legal orders" while "the emergence and expansion of the system of international [capitalist] institutions" such as the WTO "bind nation-states de jure and/or de facto." Under these conditions, Massimo D'Antona observes, "the international public order of labour law in the age of globalization is a site of values in conflict." International labor law, Alston argues, must align "itself with international human rights law around a shared task of mitigating the distributional consequences of globalization and transnational flexible production-a task in which the right to bargain collectively performs a critical function." 35

What is to be done? On the one hand, this volume suggests that older notions of unitary national legal regimes are in fact outdated, although by no means 
irrelevant. As Karl Klare notes, "increasingly legal regimes are comprised of multiple, overlapping layers of sovereignty and norm-creation" and the result is to produce "overlapping sovereignties" within and across borders. The result is a "complex multivalent legal regime," analogous to those of federal states, that is marked by a "lack of clarity on norm-hierarchy" except in the case of capital, whose "rights" are now far more powerfully entrenched than ever.

As for the idea that the passing of an historical epoch means the death of its ideals, values, and institutions, Denis Davis notes that the law has always been full of "gaps, actual contradiction, and ambiguity," and that it is the task of "legal and indeed political work" to make "old law" meaningful in new ways. ${ }^{36}$ Indeed, historian Stanley Engerman's survey of the nineteenth-century history of national labor standards legislation in England and Europe demonstrates that early arguments about national labor standards anticipated "most current claims" by their advocates or opponents on the international level. ${ }^{37}$

So what are the implications of these insights? On the supranational level, Klare suggests the need to "invent new political forms-including effective, multilateral labour rights and standards guarantees, transnational collective bargaining systems, and cross-border networks and coalitions-to solve collective action problems and to deter capital" from evading efforts by national governments or international institutions "to carve out space for social justice." On the domestic front in the North, Lucy Williams argues that we must re-imagine labor and social welfare law, our predominant emblems of "redistributive politics and transformative aspirations," by making room for notions of belonging beyond citizenship. It will also require "a certain sort of moral generosity," Langille adds; "that is, one must embark upon these debates [about globalization] with a view of global, not just local welfare." In a world in which wealth is "grotesquely maldistributed" between countries, we can no longer adopt "a purely domestic account of welfare" without being complicit with "further global injustice." 38

\section{Labor Linkages with International Trade in the Global Maritime Shipping Industry}

On November 7, 2007, the Cosco Busan cargo ship collided with the base of a bridge in San Francisco Bay, leaking 58,000 gallons of oil into the busy waterway. Four days later and thousands of miles away, four ships sank in a Black Sea storm, carrying 7,000 metric tons of sulfur to the seafloor, spilling 2,000 tons of oil, and killing five seafarers. ${ }^{39}$ Despite the importance of maritime shipping in the world economy today, such accidents are among the rare occurrences that bring this industry to the front pages of newspapers. Over 60 percent of world oil consumption and 90 percent of global trade depend on maritime shipping, a sector which grew by 121 percent from 1986 to $2006 .^{40}$ It employs a global labor force of nearly 1.2 million seafarers on a fleet of 145,000 oceangoing vessels, the largest of them as wide as ten lanes of freeway. ${ }^{41}$

Maritime shipping offers a kaleidoscopic illustration of the complexities and conundrums wrought by the transnational processes of globalization. Yet 
while recent debates over globalization have brought previously unseen workplace injustices into the limelight, the seafarers upon whom the world's economies of production and consumption depend have remained largely invisible. The mobility of capital, technology, and labor is epitomized by the maritime shipping industry, described by scholars as "the most global industry of all" where the process "began earlier and has gone deeper than in most other traditional industries." 42 A uniquely complex multinational and transnational configuration characterizes the industry: "it is not unusual," the International Maritime Organization (IMO) explains, "to find that the owners, operators, shippers, charterers, insurers, and the classification society, not to mention the officers and crew, are all of different nationalities and that none of these is from the country whose flag flies at the ship's stern."43

Today's merchant and cargo ships are marked by bewildering structures of ownership, severing links between the citizenship of proprietor, crew, and flag state as parent companies search for more malleable labor and lower safety and environmental standards. The system of open registration, which took off in the 1960s, allows vessels to register under "Flags of Convenience" (FOCs) - the International Transport Workers' Federation (ITF) term for open registries managed by states with no relationship to the citizenship of the owners or operators - in order to avoid the costs of higher rates of taxation and regulation, as well as the workforce nationality requirements of their home states. ${ }^{44}$ Owners flag their vessels and hire crews at the cheapest available rate globally, while FOCs compete actively for registrants (and thus revenues) by lowering standards and limiting regulations. Some even contract out the registry functions to third party companies.

By registering in an FOC state, a medium-sized vessel as much as halves its operating costs, saving on taxes and wages and cutting corners in maintenance, safety equipment, and training for crewmembers. ${ }^{45}$ Sixty-four percent of the global shipping fleet is registered in thirty-two FOC states-a list topped by Panama, Liberia, Bahamas, and Marshall Islands-while the parent companies are concentrated in Greece, Japan, Germany, China, and the United States. ${ }^{46}$ Meanwhile, shipping labor is supplied primarily by the Far East, Southeast Asia, and Eastern Europe, with the Philippines providing twenty percent of the maritime workforce, followed in importance by China, India, Greece, Japan, Norway, Russia, and the United Kingdom. ${ }^{47}$ Shipping vessels and their crews - stewards of human lives and valuable cargo-often operate precariously on the open seas, beyond the reach of national governments, trade unions, and environmental regulations.

But this foreboding image of maritime shipping as a lawless, "anythinggoes" industry is all but overturned by a closer examination of the sector's complexities. At the global level the industry is by no means bereft of regulatory mechanisms, institutions, and structures; indeed, it is the only industry that maintains an internationally-set minimum wage. Two recent books by social scientists Elizabeth DeSombre (2006) and Nathan Lillie (2006) demonstrate the possibilities for social justice in the context of maritime shipping through international 
negotiations and enforcement. In her study of environmental, safety, and labor standards in the industry, DeSombre examines international agreements on issues such as trade, working conditions, and pollution, as well as shifts in rates of registration among FOC states and port detention rates, to theorize about the systemic nature of regulatory dynamics. She concludes that the industry is characterized by a "race to the regulatory middle" - not a race to the bottom, as much of the literature on globalization suggests-among flag states competing for registry revenues. ${ }^{48}$

While certain FOC states tend to attract more registrants than industrialized states because of lower costs and lack of oversight, labor groups and port inspectors target the FOC vessels with the worst records. FOC states thus tend to make and enforce decisions that raise environmental, safety, and labor standards in order to avoid facing boycotts or detentions. ${ }^{49}$ Those FOC states that choose not to raise standards, in turn, suffer disadvantages when competing with higher-standard ships in the global marketplace while new entrants take their places. The same balancing mechanism is at work among owner-run classification societies, since a ship's classification impacts its reputation (and thus competitiveness) in the industry, as well as insurance costs and the likelihood of being detained or targeted by labor actions. To DeSombre, globalization in this industry is a process with a "constant and predictable evolution" whereby low-standard FOC states tend to raise standards and the industrialized states are compelled to lower them in the face of marketplace competition. ${ }^{50}$ Instead of continually descending toward the regulatory bottom, she argues, the system reaches equilibrium somewhere in between.

Nathan Lillie, in contrast, explains how transnational class struggle within the maritime shipping industry has shaped and been shaped by the FOC system. "Global governance generates new transnational political spaces," Lillie argues, "in which the terms of subordination are subject to negotiation and contestation." ${ }^{51}$ International bargaining between shipping companies and the ITF-a global union that coordinates labor actions among its maritime and nonmaritime sections-has "put a bottom on the downward spiral" in wages and workers' rights through new forms of regulation. ${ }^{52}$ Lillie's work builds upon DeSombre's schema by examining how organized labor works as a counterbalance to the downward push in standards in the global maritime industry. In 1948, the ITF launched a campaign to improve labor and safety standards for seafarers on FOC ships. An umbrella organization "for pooling union authority [and ... ] coordinating national activity in systematic ways" at the global level, the ITF has negotiated agreements with nearly 5,000 FOC vessels, covering over 90,000 seafarers. ${ }^{53}$ The FOC campaign, Lillie claims, "reasserted social control over an offshore industry" and utilized innovative organizing strategies that transcended the North-South divide. While he has likely overstated the ITF's level of influence and its ability to overcome deep divisions among unions at the global level, it is clear that the ITF network is a force with which ship owners must contend, constituting "a powerful global and transnational actor within the shipping industry." 54 
Ports provide the single most important point of leverage for maritime labor in obtaining new agreements and enforcing existing ones. The ITF exploits the interdependent processes of cargo transport at sea and handling on shore, using the greater degree of industrial leverage held by locally-based dock workers to bolster seafarers' bargaining power. ${ }^{55}$ Labor actions such as boycotts depend upon port-based affiliate unions (usually longshoremen, tugboat pilots, and/or lock operators) to deny noncompliant ships access to port services at the point of loading, unloading, or exiting a port. ${ }^{56}$ Ship inspectors, also affiliated with local unions, provide the link between sea- and land-based shipping operations, providing information to the global ITF network concerning which ships are in compliance and which should be targeted for further action. Although the number of seafarers covered by ITF agreements $(90,000)$ is small in the context of the total labor force of 1.2 million, the organization's hard-won accomplishments offer encouraging news about the possibility of advancing workers' rights.

The ILO has given more attention to maritime shipping labor than to any other group (followed by the related dock workers and fishing sector), with 39 of its 185 total conventions pertaining to the industry. ${ }^{57}$ Parallel to the ITF system, the ILO hosts a tripartite bargaining process that brings seafarers, ship owners, and states together to negotiate international conventions related to wages and safety standards at sea. The disagreements concerning Port State Control in the 2004 ILO negotiations underscore the strategic importance of ports in the bargaining process. ${ }^{58}$ States and ship owners resist the obligation to inspect and detain ships on the basis of labor rights, but seafarers insist that the enforcement of such rights is essential to their approval: "without [a viable enforcement regime] the rest of the convention is meaningless." ${ }^{, 59}$ Since 1946, the ILO has also made formal recommendations for a global minimum wage for seafarers through the bipartite (employers and unions) Joint Maritime Commission. ${ }^{60}$ The wage it sets is comparable to what Lillie identifies as the median market rate for seafarers on non-ITF ships. ${ }^{61}$

DeSombre and Lillie both emphasize that states are by no means irrelevant in this most globalized of world industries. Even though some FOC states abdicate part of their sovereignty by contracting out the functions of their ship registries, DeSombre points out that the system is ultimately controlled by nation-states, not corporations acting independently of state control. ${ }^{62}$ Lillie, on the other hand, believes that in the context of globalization, state power and the transnational class structure are fragmenting along industry lines. ${ }^{63}$ He nonetheless recognizes that the ITF as a global union is dependent upon its constitutive national unions for legitimacy and access to members. ${ }^{64}$ Furthermore, "national origin remains an important part of the identity of many firms and ship owners," and national groups sometimes negotiate directly with the ITF. ${ }^{65}$ In a sense, the ITF's Flag of Convenience campaign itself is based on the assumption that, even in the context of a globalized industry and workforce, there is a natural relationship between capital, labor, and nation-states that should be upheld, since it specifically targets ship owners who flag outside their countries of origin. ${ }^{66}$ 
Yet inequalities persist among flag states in their power to implement and enforce environmental, safety, and labor regulations on the ships owned by their nationals or flagged in their registries. Rather than offering a triumphalist story, the studies by DeSombre and Lillie help to shed light on how clashing interests among states, ship owners, and seafarers in the global maritime industry open up space for collective action and international regulation. In the context of an international maritime regulatory regime, organized labor has advanced its cause by creating a global union structure that seeks to protect seafarers working in an otherwise stateless realm while delineating minimum standards for wages and working conditions that at least some ship owners have agreed to uphold.

\section{Promoting Labor Rights: Corporate Codes of Conduct and International Consumer Campaigns}

In the global economic system over the last several decades, winning broadbased support for labor rights has been made more difficult by the extreme mobility of capital, which limits the ability of the nation-state to tax or regulate corporations and protect workers. One response was a shift in activist strategies toward a new source of leverage against corporations: consumer markets. In Beyond the Boycott (2007), sociologist Gay Seidman investigates three transnational campaigns to improve industry-wide standards through independent corporate monitoring by NGOs. ${ }^{67}$ Using interviews and secondary sources, she examines three contrasting experiences (1) in apartheid South Africa, where the Sullivan Principles of 1977 'the first 'successful' example of independent monitoring,"68 utilized a voluntary code of conduct to encourage US companies to promote workplace equality; (2) in India, where since 1994 the "Rugmark" social labeling program endorsed handwoven rugs produced without child labor and sold in European and US markets; and (3) in the Guatemalan garment industry, where workers and activists struggled to improve working conditions and build a "culture of compliance" with labor rights and standards following the end of the country's ghastly civil war.

Seidman's case studies allow her to explore "the kinds of campaigns, networks, and labor activism that have prompted companies to accede to external monitoring" in the post-1990s era and how and why certain programs are successful. ${ }^{69}$ Such monitoring is part of a continuum that includes voluntary corporate or industry-wide codes of conduct, which can be self-administered or independently monitored (Seidman's focus). ${ }^{70}$ Her account challenges celebratory notions by focusing on their "complicated, often messy reality" while exploring their tensions and limitations. ${ }^{71}$

Shaped by past lessons from international human rights movements, Seidman suggests, some transnational activists have adopted a "stateless" approach by advancing claims about universal rights and morality rather than those gained through national citizenship. ${ }^{72}$ While acknowledging that US and European consumer markets can provide vital leverage, she cautions that 
in reframing their discourses toward distant global audiences, transnational activists may inadvertently obscure concerns about the empowerment and protection of workers through the strengthening of local and state institutions. These campaigns may be "more likely to help workers 'bear witness' and gain international sympathy than to negotiate with managers on their own behalf."73

Conflicts among local and transnational activists in two of Seidman's cases underscore the weakness of voluntary monitoring schemes. The monitoring system implemented under the Sullivan Framework was plagued by problems. Carried out by Arthur D. Little accountants, it relied on data provided by the companies themselves without any verification process. Furthermore, its emphasis on philanthropy led corporations to focus disproportionately on making donations to black community organizations, while sidestepping their commitment to improving equality within the workplace. ${ }^{74}$

The Rugmark program, on the other hand, has been hailed as a successful consumer-based strategy to protect children from exploitative labor practices. $^{75}$ However, Seidman notes that several Indian scholars have criticized the label as little more than a marketing scheme, and the United Nations Children's Fund (UNICEF) ended its sponsorship of the program a few years after it started. ${ }^{76}$ Some consider the Rugmark monitoring system ill-equipped to handle an industry based on home work, where children labor in sheds in remote villages. Inspections by NGOs were neither comprehensive nor frequent enough to prevent exporters from exploiting loopholes in the system. ${ }^{77}$ Consumers often have limited access to these practical details and see only the "rubber stamp" 78 of a social label or corporate image, unaware of the possible cooptation of the monitoring process.

Instead, Seidman reminds us of the importance of nation-states to the success of labor-consumer campaigns. The efforts of transnational activists would be most effective, she believes, if directed at "shoring up weak states" and "reinforcing national institutions rather than trying to replace them with even weaker NGOs."79 National governments, particularly in countries with strong consumer markets, can contribute greatly by pressuring negligent exporting countries to improve labor conditions or face trade sanctions - a tactic used in each of these campaigns. ${ }^{80}$ Exporting states could also help build effective monitoring schemes if they employed competent factory inspectors and pressured companies to enforce workplace standards. ${ }^{81}$

On the other hand, the anti-sweatshop movement in Guatemala testifies to the power of transnational solidarity movements as a foundation upon which a framework of accountability can begin to be established. In the wake of a decades-long civil war that claimed the lives of 200,000 people, civil-society groups and their international supporters shifted to focus on workers' rights in the notoriously harsh export-oriented assembly plants known as maquiladoras. Throughout the $1980 \mathrm{~s}$ - while violent paramilitaries or state forces repeatedly targeted trade unionists - the garment industry increasingly relocated production to Central America for export to the United States under the Caribbean Basin Initiative (CBI). This duty-free trade preference 
program was originally proposed in 1982 by President Reagan as part of a multifaceted US effort to defeat revolutionary movements in Central America. Once implemented, exports to the United States from Guatemala and other CBI producers more than doubled between 1984 and $1993 .{ }^{82}$

Yet the CBI does not derive strictly from US strategic objectives in its selfstyled "backyard." Indeed, it is closely related to international trade disputes between the United States and Far Eastern producing countries that chafed at restricted country quotas for their exports to the United States under GATT's Multifiber Arrangement (MFA), a protectionist measure from 1974 that partially sheltered the domestic garment and textile industries in developed countries (now phased out under the WTO). The CBI also involved disputes within the United States that pitted importers against US producers, as well as splits between the textile sector and a shrinking domestic garment industry. As with NAFTA, the rules of CBI are designed so that a CBI-produced shirt has a larger percentage of US domestic content than Far Eastern imports. ${ }^{83}$

Most importantly, the CBI in 1983 was also the first of several pieces of US trade legislation (including the Generalized System of Preferences, or GSP, in 1984) to make the IRWR provision a condition for enjoying unilateral US trade concessions that allowed duty-free access. ${ }^{84}$ Indeed, the explicit link established between labor and human rights during the Guatemalan genocide set the stage for ongoing labor rights struggles as civil society sought to build democratic institutions in the post-civil war era. Relationships built among transnational and local activists through decades of human rights solidarity work gave strength to the anti-sweatshop movement of later years. With easier access to local knowledge, such networks "gave a different impetus to debates about workplace monitoring," enabling them to better respond to communities' concerns and channel support where it was most needed. Seidman thus concludes that the most promising means for "expand[ing] democratic citizenship" would be to assist those struggling for domestic political change by adopting "state-centered strategies" that aim to strengthen local and national institutions. $^{85}$

Ralph Armbruster-Sandoval also seeks hope in the Central American antisweatshop movements. ${ }^{86}$ Globalization and Cross-Border Labor Solidarity in the Americas uses case studies in Guatemala (Phillips-Van Heusen), Honduras (Kimi), El Salvador (The Gap), and Nicaragua (Chentex) to ask why, despite short-term victories, these transnational campaigns were unable to achieve lasting gains. One after another, Armbruster-Sandoval describes the hard battles and grave disappointments encountered by workers and activists in these Central American maquiladora struggles. Yet he avowedly rejects the "gloomy perspective" of analysts who portray workers as "hapless, powerless victims" pitted vainly against powerful corporations. "Resistance is possible," he writes resolutely. "Capital is not omnipotent." 87

What lessons can contemporary scholars and activists learn from the limited impacts to date of these campaigns? Like Seidman, Armbruster-Sandoval argues that strong ties between local and transnational activists (what he terms 
"organization-building politics" ${ }^{88}$ ) are key to the success of cross-border labor solidarity movements. ${ }^{89}$ Through company-specific empirical studies, he provides an in-depth, phase-by-phase analysis of strategies used, their weaknesses, and the sources of disunity among the actors in play. ${ }^{90}$ For the Phillips Van-Heusen Workers Movement of Guatemala ( $\mathrm{PVH})$, for example, he examines union strength, unity within the "transnational advocacy network" (TAN), and political strategies. The Camisas Modernas Workers' Union (STECAMOSA) fought for ten years with disheartening results: in 1997 it finally won a two-year contract to become the only maquiladora in Guatemala with a union contract but the plant closed one year later and left 500 people jobless. ${ }^{91}$ Material and moral leverage were important, he concedes, but it was only when both STECAMOSA and its relationship with the TAN were at their strongest, at the height of the contract negotiations, that the movement achieved its goal of winning better wages and working conditions. ${ }^{92}$ Armbruster-Sandoval finds parallels with his other three case studies. ${ }^{93}$

Armbruster-Sandoval consistently highlights the positive in each of these four campaigns, even though they resulted in only limited gains for the workers themselves (The Gap), or worse: plant closures and union dissolution (PVH, Kimi, Chentex). Capital mobility and corporate intransigence, it would seem, can easily trump transnational labor solidarity movements although he avoids portraying them as simple failures by drawing political inspiration from their short-lived successes. The heroes of his story are the "sweatshop warriors" who organize to demand justice, ${ }^{94}$ and their distant partners in the "first world" who challenge the status quo of consumer society through boycotts. In the end, he concludes that the problem is fundamentally structural: "the [anti-sweatshop] movement's gains will remain ephemeral until neoliberal capitalism ... is challenged and ultimately replaced." Only "systemic change" will allow the victory of labor rights and popular democracy.

\section{Why Trade-Linked Worker Rights Mechanisms? And How They Work}

As with most international labor rights advocates, Seidman and Armbruster-Sandoval do not believe that corporate social responsibility alone can resolve the injustices that lie behind the goods appearing on the shelf of a US Wal-Mart store. The division of the gains from producing a pair of pants sold in the United States illustrates the radically skewed nature of our existing international trade and investment regime. As every US Students Against Sweatshops (USAS) campaign notes, the Guatemalan or El Salvadoran woman worker receives fifteen cents of pay for every $\$ 16.96$ pair of pants sold. ${ }^{96}$ And when the workers try to organize or fight back, they are fired with impunity in a labor-surplus world where there are lots of other production sites and hungry people eager to work for even those meager wages. ${ }^{97}$ Indeed, the inverse relation between the distance from actual production and the distribution of the rewards exists even within the world of business, where profits cluster disproportionately at the top of the supply chain. ${ }^{98}$ 
So what is to be done while awaiting the fundamental systemic change that constitutes the far horizon of utopian possibility in Seidman and Armbruster-Sandoval? Here we need to turn back to a classic 1998 book by Henry Frundt from which they draw. Trade Conditions and Labor Rights: U.S. Initiatives, Dominican and Central American Responses makes a strong but sober case for the utility of trade-linked measures to discipline governmental and employer abuses of labor rights. Carefully attuned to the politics of domestic labor relations within each CBI country, it guides us through the larger supra- and transnational framework provided by the GSP IRWR petition mechanism. $^{99}$

As predicted by its US advocates in the 1980s, the GSP's linkage of labor rights and standards to a trade-sanctioned enforcement mechanism has proven valuable in focusing government attention on labor rights in less developed countries (LDC). The GSP's investigatory and adjudicatory mechanisms have achieved positive results far more quickly and effectively precisely because labor rights are tied to trade benefits, however modest in monetary terms. For our purposes, the US GSP review process can be contrasted with the ILO review mechanisms that would be used in a proposed WTO worker rights clause. Unlike the GSP, the ILO conducts its reviews on a multilateral and professional basis, although to limited effect since existing ILO oversight monitoring is strictly limited to moral suasion.

Despite a unilateral IRWR review process flawed by political calculation, ${ }^{100}$ the potential monetary loss through denial of duty-free privileges introduces an important new element in government and industry thinking. As a recurring headache for government officials and businessmen, the IRWR review increases the policy focus on labor within governments where the labor ministry is usually one of the weakest portfolios; more importantly, it opens a venue where worker and union voices-normally ignored-have a place, however limited. This is especially important in countries like Guatemala, where the formidable obstacles to worker self-organization include, in the words of one union leader, "corruption, the capricious application of work laws and delayed judicial procedures," as well as institutional "deformities and deeply rooted viciousness." Other trade unionists offer similar evaluations: without GSP reviews, "things would be much worse. ... It has preoccupied the elites and this has been helpful ... [and] afforded greater space for union action."101 At a minimum, it saved some lives, modified some bad labor laws, and touched the lives of some workers positively.

By creating a structure of incentive with reporting and follow-ups, the IRWR review process also creates options that can be taken up by new individuals who come to occupy those administrative positions. Even the turnover among office holders can make for substantive progress when a new appointee commits his institutional capital and personal prestige to the process. In terms of a positive effect at the margin, good things for workers' concrete struggles can happen when the individual occupying a post, such as US ambassador, GSP review chief, Labor Minister, or head of the employers association, acts out of 
a good faith devotion to democracy, for reasons of personal morality, the search for political advantage, or purely as a result of getting irritated with bureaucratic run-arounds.

In a very real sense, Frundt offers a vision of the nitty-gritty of how a statecentric international labor rights process with coercive power might work to enhance domestic leverage for workers. Positive results would be powerfully enhanced if such pressure was combined with international funding to build the government's enforcement capacity. As Frundt notes, "it is difficult for readers north of the Rio Grande to appreciate the virtual paralysis of statefunded institutions in carrying out and enforcing the basic labor rights that legally exist in Basin countries." 102 Indeed, labor rights advocates are well aware that carrots, at least as much as sticks, are needed in dealing with poor countries. Reliable funding to improve labor law enforcement could be generated by one of the primary proposals of the alt-global movement that debuted at Seattle: a modest tax on international currency transactions, first proposed by Nobel Prize-winning economist James Tobin in 1972, that could be used to channel resources towards those outside of globalization's winners' circle.

Frundt's book convincingly illustrates what a powerful systemic change an international worker rights or social clause would be if it were implemented-as proposed-through the ILO-WTO, with an emphasis on democratic selforganization by working people as a fundamental human right. ${ }^{103}$ That the question at stake has to do fundamentally with a conflict of values is illustrated by an anecdote recounted in 2003 by Princeton economics and public affairs professor Alan Krueger: "To make conversation at a dinner party at the World Economic Forum in Davos, I once asked the then-finance minister of Pakistan whether child labor was a problem in his country. Perhaps thinking I was a potential investor, he replied, 'No, child labor is not a problem. You can hire all the children you want.' This story reminds me that there are many different perspectives that one can take on child labor.",104

\section{How Do We Get There From Here? The Politics of International Labor Rights Advocacy}

This essay has reviewed only a small part of a flourishing literature on the social and democratic deficits of the existing international trade and investment regime highlighted at Seattle in 1999. During the same year, the creative mass action of a new generation of US student activists demonstrated the moral sensitivity of institutions and consumers in the North about goods produced under inhumane, poorly-remunerated, and exploitative working conditions. ${ }^{105}$ The success of US Students Against Sweatshops (USSAS) depended, in part, on its interface with an older generation of cross-border solidarity activists whose contributions were detailed by Armbruster-Sandoval, Frundt, Greven, Ross, and Seidman. As this essay has argued, the credibility and long-term success of these vital market-oriented campaigns and cross-border solidarity initiatives 
are enhanced when they take up the struggle to implant an international legal regime of worker rights linked to trade.

But what intertwined economic dynamics and political arguments would we need to implant such a social clause in "a transnationalized world economy and a lopsided world geopolitical structure characterized by complex economic, political, and ideological conflicts and crosscurrents"? ${ }^{106}$ A 2004 volume by Robert Ross titled Slaves to Fashion: Poverty and Abuse in the New Sweatshop goes furthest toward answering these questions in a compelling and accessible manner. The positive features of his eminently teachable, well-illustrated, and richly documented book are many. First, he convincingly explicates the linkages between the international and domestic economy (the intermestic) and grounds them in a conversation with US readers. Second, he emphatically rejects the idea that the problem of labor rights is "over there, never here; sweatshops are the past, or they are elsewhere; they are not us, not now." 107

Grounding his story in a deep historical understanding of the US garment and textile industry, the first third of Ross's book begins with garment sweatshops and the Triangle Shirtwaist fire of 1911 and then traces the improvements that flowed from unionization and the 1938 passage of the Fair Labor Standards Act (the domestic equivalent, as he notes, of a minimum international labor standard). He then traces the gradual deterioration of conditions that followed, which included a diminution of union power and the adoption of a deregulatory and increasingly anti-labor stance by the federal government. Parallel to these developments, US employment in the industry dropped from a 1973 highpoint of 1.4 million workers to 660,000 by the 1990 s; of these, 265,000 work under sweatshop conditions, according to his calculations. ${ }^{108}$

Ross's story of labor abuse and the search for its remedies is thus grounded in US history and conditions. In doing so, he establishes that labor exploitation and government neglect characterize both rich countries like the United States and those poor countries whose workers now provide more than half of US apparel imports. This posture also allows him to avoid dichotomizing a concern for working people abroad against those at home (a political dead end to those suffering here), while combating an aggressive US smugness that alienates foreigners. As he clearly demonstrates, "any fairminded international comparison of apparel industry labor conditions and labor rights... will find the [contemporary] United States wanting in law and enforcement," much as is true elsewhere. ${ }^{109}$ In explicitly combating US exceptionalism, Ross shares common terrain with a 2000 volume by the pioneering international labor rights scholar Lance Compa. Unfair Advantage: Workers' Freedom of Association in the United States under International Human Rights Standards indicted the United States not only for its violations of ILO Conventions for freedom of association and the right to collectively bargain (which the United States refuses to ratify), but for how its own laws are twisted by anti-labor bias and the profoundly structured inequalities of the United States. ${ }^{110}$ 
The second half of Ross's book moves to the international level by tracing the global supply chain in apparel while utilizing anecdotes and documentation from his own involvement in the campaigns of the legendary international labor rights advocate Charles Kernhagen and his National Labor Committee ("the man who made Kathie Gifford cry," as he is known). In doing so, he explicates the North/South dimension of our riven capitalist world while building a convincing case for "Solidarity North and South" (the title of Chapter Twelve) that would include an international worker rights or social clause in the WTO. As he puts it, "if labor standards are to improve (or even be stabilized) there is little alternative" but to create some type of "enforceable international regulatory structure." 111 In the words of labor lawyer Brian Langille in 1997: "We are at a point where ... labor and other social policies are increasingly ... being set internationally - that is unavoidable.... The issue is whether they should be established by the international market-place in labor policy or by international agreement."112

In a context of enhanced tensions, anxieties, and anger, the international protest cycle of 1999-2003 spoke to the feeling that the world's peoples had collectively lost control of their lives and the markets in which they live. Despite its manifold ambiguities and utopianism, "social clause" advocacy shows that even the most powerful and richest nations can no longer rely on exclusively national or nationalist solutions in our intertwined world. "Whether in China or the United States, the challenges facing working- and middle-class peoples in a global political economy will never be resolved on a purely national basis. Even in the best of circumstances, enhanced trade union organization within a given country, even with new political and legislative conquests, is not enough unless one addresses the governance of the global political economy."113

The criticism of contemporary "globalization," which first gained prominence at Seattle, will intensify in the coming years. To advance, we need a clarity and boldness in our stated objectives: to build a social dimension of the international trade and investment regime. And we should not be discouraged, as Robert Ross argues, by the fact that "the more permanent and far-reaching solutions to labor abuse are located at the global level—where the politics are so complicated that any conceivable time horizon of success ranges far into the future. So be it. That the task is long-range is not an argument against it: what is required is a strategic vision that is plausible," based on lessons drawn from the historical experience of workers, their unions, and allies. There is much work still to be done. ${ }^{114}$

\section{NOTES}

1. Lance Compa and Stephen Diamond, eds. Human Rights, Labor Rights, and International Trade (Philadelphia, 1996), 2.

2. John D. French, "From the Suites to the Streets of Seattle: The Unexpected Re-Emergence of the 'Labor Question,' 1994-1999," Labor History 43 (2002): 285-304; French, Globalizing Protest and Policy: Neoliberalism, Worker Rights, and the Rise of Alt-Global Politics, forthcoming. 
3. Compa and Diamond, Human Rights, Labor Rights; John D. French, "Comercio y Trabajo en el Mundo: Hacia la Cláusula Social," Nueva Sociedad 148 (1997): 142-57; Steve Charnovitz, "Trade Employment, and Labour Standards," Temple International and Comparative Law Journal, 11 (1997); Nigel Haworth and Steve Hughes, "Trade and International Labour Standards," Journal of Industrial Relations 39 (1997): 179-95; Rorden Wilkinson and Steve Hughes, "Labor Standards and Global Governance," Global Governance 6 (2000): 259-277; Robert O'Brien, Anne Marie Goetz, Jan Aart Scholte, and Marc Williams, Contesting Global Governance: Multilateral Economic Institutions and Global Social Movements (Cambridge, 2001); Ronaldo Munck, Globalisation and Labour (London, 2002).

4. John D. French, "Wal-Mart, Retail Supremacy, and the Relevance of Political Economy," Labor: Studies in Working Class History of the Americas 4 (2007): 38-39.

5. World Bank, Workers in an Integrating World (Oxford, 1995), 9.

6. Steven Sanderson, The Politics of Trade in Latin American Development (Stanford, 1992), 10, 212.

7. Sanderson, Politics, 144.

8. World Bank, Workers, 248-249.

9. Herbert Feis, "International Labour Legislation in the Light of Economic Theory," International Labour Review (ILR) 15 (1927): 491-518.

10. Ibid., 491.

11. The reports share the common title, Monitoring International Labor Standards (Washington, 2003-4), which includes written statements from 2002-2003 forums held in New York and Los Angeles, Costa Rica, Sri Lanka, and South Africa: Summary of Domestic Forums (2003); Human Capital Investment: Summary of a Workshop (2003); Techniques and Sources of Information (2004); International Perspectives: Summary of Regional Forums (2004).

12. NRC, Monitoring: Techniques, 3-4.

13. W.R. Böhning, Labour Rights in Crisis: Measuring the Achievement of Human Rights in the World of Work (New York, 2005), xiv, 12, 13.

14. Steve Charnovitz, "Fair Labour Standards and International Trade," Journal of World Trade Law 20 (1986): 68; Norbert Malanowksi, "Social and Environmental Standards in International Trade Agreements," in Social and Environmental Standards in International Trade Agreements, ed. Malanowksi (Munster, 1997), 2; Gloria Muller, "Foreword," In Malanowski, Social, 7, 9; Virginia Leary, "Workers' Rights and International Trade," in Fair Trade and Harmonization, Volume 2: Legal Analysis, ed. Jagdish Bhagwati and Robert E. Hudec (Cambridge, 1997), 178; Erika de Wet, "Labor Standards in the Globalized Economy," Human Rights Quarterly 17 (1995): 445; Philip Von Schöpenthau, "La Cláusua Social: Un Arma Inadecuada En La Lucha Por Los Derechos Humanos y Las Normas Sociales,” in La Cláusua Social: ¿Una Estrategia Sindical Ante La Liberalización Comercial, ed. Günther Maihold and Guillermo Villalobos Sole (San José, 1995), 21-22; OECD and Corinne Deléchat, et al., Trade, Employment and Labour Standards: A Study of Core Workers' Rights and International Trade, (Paris, 1996), 11.

15. Steve Charnovitz, "The Influence of International Labor Standards on the World Trading Regime," ILR 126 (1987): 580.

16. John D. French, "Trade Unionism and the Fight to Reshape the World That Trade Built: International Worker Rights in a Globalizing World, 1959-1999," in Labour and New Social Movements in a Globalizing World System, ed. Berthold Unfried and Marcel van der Linden (Linz, 2004), 155-178.

17. On US government policy-making: Edward C. Lorenz, Defining Global Justice: The History of U.S. International Labor Standards Policy (Notre Dame, 2001).

18. Thomas Greven, Clash of Globalizations? The Politics of International Labor Rights in the United States (Frankfurt am Main/New York, 2003), 89-90.

19. John D. French, "North American Free Trade Agreement," in Encyclopedia of US Labor and Working Class History, ed. Eric Arnesen (New York, 2006).

20. John D. French, "Labor and NAFTA: Nationalist Reflexes and Transnational Imperatives in North America," in Labour and Globalisation, ed. Ronaldo Munck (Liverpool, 2004), 149-165.

21. Jagdish Bhagwati, In Defense of Globalization (New York, 2004).

22. Nirvikar Singh, "The Impact of International Labor Standards [Comment by T.N. Srinivasan]," in Kaushik Basu, Henrik Horn, Lisa Román and Judith Shapiro, eds., International Labor Standards: History, Theory, and Policy Options (Malden, 2003), 107. 
23. Deepak Lal, Resurection of the Pauper-Labour Argument, (London, 1981).

24. Robert Ross, Slaves to Fashion: Poverty and Abuse in the New Sweatshops (Ann Arbor, 2004), 121-122; 288.

25. Ross, Slaves, 323-330, examines these fallacies in a section titled "are sweatshops good for you." A proglobalization tract by free trade economist Pietra Rivoli showed creativity in its research: The Travels of a T-Shirt in the Global Economy: An Economist Examines the Markets, Power and Politics of World Trade (Hoboken, N.J, 2005).

26. Basu et al, International, 186.

27. Robert Flanagan, "Labor Standards and International Competitive Advantage," in Robert Flanagan and William Gould, eds., International Labor Standards: Globalization, Trade, and Public Policy (Stanford, CA., 2003), 47.

28. Gavin Kitching similarly defends globalization as an "enormous benefit to the poorest and most oppressed." In a provocative, if anguished, book, this one-time leftist development economist of Africa explains how he came to his antinationalist third position. In his despairing vision of a world divided, he opts for the poorest of the world's poor in face of what he deems to be ignorant and nationalistic protestors at Seattle. [Seeking Social Justice through Globalization: Escaping a Nationalist Perspective (University Park, PA., 2001), xiv, 308].

29. Bob Hepple, Labour Laws and Global Trade (Oxford, 2005), xii, 3, 16, 135, 271, 274. Unlike Hepple, Philip Alson is skeptical that transnational and domestic law is being woven together even in the European Union whose "approach to collective labour rights enforcement within member state is piecemeal, a product of limited competences and of an apparent lack of political will" (Philip Alston, ed Labour Rights as Human Rights [Oxford, 2005], 20). For an empirically-driven study: Varun Gauri and Daniel M. Brinks, eds., Courting Social Justice: Judicial Enforcement of Social and Economic Rights in the Developing World (Cambridge, 2008).

30. Hepple, Labour, 20-21.

31. Ibid., 3, xi. In his vocabulary, "neoliberal" refers to right-wing Thatcherites, not Bill Clinton or Tony Blair.

32. Bob Hepple, ed., Social and Labour Rights in a Global Context: International and Comparative Perspectives (Cambridge/New York, 2002), 2. 27,51 .

33. Lord Wedderburn, "Common Law, Labour Law, Global Law," in Hepple, ed., Social,

34. Joanne Conaghan, Richard Fischl, and Karl Klare, et al., eds., Labour Law in an Era of Globalization: Transformative Practices and Possibilities (Oxford, 2002), 23, 171.

35. Ibid., 1, 3, 23, 25, 40 143. Alston, Labour Rights, 14.

36. Ibid., 27, 171.

37. Stanley L. Engerman, "The History and Political Economy of International Labor Standards," In: Basu et al., International, 29-30.

38. Conaghan et al., eds., Labour Law, 27, 113, 139.

39. Chloe Arnold, "Russia: Oil Spill Highlights Tragic Environmental Legacy," Radio Free Europe Nov. 28, 2007; BBC News, "Black Sea faces environmental "catastrophe," BBC News Nov. 13, 2007.

40. International Maritime Organization (IMO), International Shipping and World Trade, Facts and Figures, available from http://www.imo.org/includes/blastDataOnly.asp/ data_id\%3D20166/InternationalShipping2007.pdf (updated October 2007, accessed Nov. 30, 2007); Peter Burgherr, "In-depth analysis of accidental oil spills from tankers in the context of global spill trends from all sources," Journal of Hazardous Materials 140 (2007): 245-256.

41. IMO, International Shipping, 18, 25; Paul Rogers, "Obstacles in San Francisco Bay put Big Ships on 'Full Alert," San José Mercury News Nov. 11, 2007.

42. Nathan Lillie, A Global Union for Global Workers: Collective Bargaining and Regulatory Politics in Maritime Shipping (New York, 2006), 10; Elizabeth DeSombre, Flagging Standards: Globalization and Environmental, Safety, and Labor Regulations at Sea (Cambridge, 2006), 13.

43. IMO, International Shipping, 26.

44. DeSombre, Flagging, 4; Lillie, Global, 42. For a thorough study of this campaign's early development, see Herbert Northrup and Richard Rowan, The International Transport Workers' Federation and Flag of Convenience Shipping (Philadelphia, PA, 1983).

45. Lisa Buckingham and Pauline Springett, "Those in Peril on the Seas," The Guardian (London) Mar. 22, 1997, 28. 
46. IMO, International Shipping, 7, 9; in 2008 the ITF listed a total of 32 Flags of Convenience states, including several landlocked countries such as Bolivia [ITF, "FOC Countries," available from http://www.itfglobal.org/flags-convenience/flags-convenien-183.cfm (accessed Aug. 27, 2008)].

47. IMO, International Shipping, 26. Nathan Lillie reports that the monthly median wage for an Able Seaman ranges from about five to 22 times higher than the wage for an onshore industrial worker from the same country, depending on the nationality of the worker (Lillie, Global, 41).

48. DeSombre, Flagging, 3.

49. Ibid., 53, 55 .

50. Ibid., 228.

51. Lillie, Global, 7.

52. Ibid., 1-2.

53. Ibid., 16; ITF, "Flags of Convenience." One study cited by Lillie estimates that a seafarer working on a ship with an ITF contract earns as much as $50 \%$ more than s/he would if receiving the market wage rate on a non-ITF ship (Lillie, Global, 40).

54. Lillie, Global, 143.

55. Ibid., 65-66.

56. Ibid., 145; see also 65-88.

57. Ibid., 110.

58. This refers to the Preparatory Technical Maritime Conference of September 2004 (Ibid., 115).

59. Ibid., 116.

60. Ibid., 50 .

61. Ibid., 40.

62. DeSombre, Flagging, 210, 216-217.

63. Lillie, Global, 7.

64. Ibid., 16.

65. Ibid., 10.

66. The ITF decides whether to designate an open registry as a FOC based on "whether the nationality of the shipowner is the same as the nationality of the flag" [ITF, "Flags of Convenience Campaign," available from http://www.itfglobal.org/flags-convenience/index.cfm (accessed Nov. 30, 2007)].

67. Gay Seidman, Beyond the Boycott: Labor Rights, Human Rights, and Transnational Activism (New York, 2007).

68. Ibid., 47.

69. Ibid., 10.

70. For a wide-ranging treatment of business ethics and "corporate social responsibility" with detailed company studies: Laura Pincus Hartman, Denis Arnold, and Richard Wokutch, eds., Rising above Sweatshops: Innovative Approaches to Global Labor Challenges (Westport, 2003).

71. Seidman, Beyond, 11.

72. Ibid., 17, 28.

73. Ibid., 34, 37.

74. Seidman, Beyond, 61-62.

75. A similar international child labor campaign resulted in a partnership agreement in 1997 between the ILO, UNICEF, and business interests in Sialkot, Pakistan, which produces seventy five percent of the world's hand-stitched soccer balls, to deal with the twenty percent of the total workforce that were children (Flanagan and Gould, eds., International, 220-221).

76. Seidman, Beyond, 73.

77. Ibid., 91-92.

78. Ibid., 63.

79. Ibid., 139. Labor rights monitoring NGOs, a business scholar noted, include both groups who "wholeheartedly" embrace cooperation with, and financing from, companies and those who opt for a more strictly confrontational strategy (USSAS, unions). From a company point of view, the result is a "good cop, bad cop" routine in which "radically divergent tactics of confrontations and cooperation" prove highly complementary. [Michael Santoro, "Philosophy Applied I: How Nongovernmental Organizations and Multinational Enterprises Can Work Together to Protect Global Labor Rights," in Hartman, et al., Rising, 109-110).

80. Ibid., 7. 
81. Ibid., 140.

82. Ibid., 107-109; Henry J. Frundt, Trade Conditions and Labor Rights: U.S. Initiatives, Dominican and Central American Responses (Gainesville, 1998), 6, 86-87.

83. Ellen Rosen, Making Sweatshops: The Globalization of the U.S. Apparel Industry (Berkeley, 2002), 145-146.

84. Greven, Clash, 82-84.

85. Seidman, Beyond, 120, 143.

86. Ralph Armbruster-Sandoval, Globalization and Cross-Border Labor Solidarity in the Americas: The Anti-Sweatshop Movement and the Struggle for Social Justice (New York, 2005).

87. Ibid., 9.

88. Ibid., 49.

89. Ibid., 25. The activists involved actively reflected on their own practice: Stephen Coats "Free Trade and Labor Cooperation across Borders: Recent U.S./Guatemalan Experiences," Latin American Labor News, 8 (1993): 10, 11.

90. See Ibid., 22-23 drawing on Margaret Keck and Kathryn Sikkink's typology of strategies: information, symbolic, leverage, and accountability [Activists Beyond Borders: Advocacy Networks in International Politics (Ithaca, 1998)].

91. Armbruster-Sandoval, Globalization, 31.

92. Ibid., $51,58$.

93. Ibid., 83-84, 104-105, 132.

94. Ibid., 107, 107n2; the term "sweatshop warriors" comes from Miriam Ching Yoon Louie, Sweatshop Warriors: Immigrant Women Take on the Global Factory (Boston, 2001), $3-4$.

95. Armbruster-Sandoval, Globalization, 153.

96. Rosen, Making, 242.

97. See the classic essay by the Nobel Prize-winning economist W. Arthur Lewis, "Economic Development with Unlimited Supplies of Labour," in A.N. Agarwala and S.P. Singh, eds., The Economics of Underdevelopment (London, 1969), 401-449.

98. Ross, Slaves, 125-146; Nelson Lichtenstein, ed., Wal-Mart: The Face of Twenty-First-Century Capitalism (New York, 2006).

99. Frundt, Trade. For a sample GSP petition on Guatemala filed in June 1990: see Jim Sugarman, Field Guide to Labor Rights (Washington, 1993), 47-57. See also David LaWare, "Solidarismo in Costa Rica: The AFL-CIO Charges Labor Rights Violations," Latin American Labor News, 10-11 (1994): 6, 14-15.

100. The controversy over the GSP IRWR clause in the Reagan/Bush era stemmed from its use to achieve U.S. Cold War foreign policy objectives. Advocates contested this distorted administration in court: Terry Collingsworth, "International Worker Rights Enforcement: Proposals Following a Test Case." In Human, ed. Compa and Diamond, 227-250.

101. Frundt, Trade Conditions, 152-153, 141, 257, 264-265, 266.

102. Ibid., 32.

103. Ross, Slaves, 280-299, for an intro to the WTO social clause debate; also French, "Comercio."

104. Kruger, In Basu, et al., International, 248.

105. Ross, Slaves, 249-266, offers a sociological analysis of the emergence of student sweatshop activism with a sympathetic evaluation of activist outlooks.

106. French, "Wal-Mart," 39.

107. Ross, Slaves, 9.

108. Ross, Slaves, 44, 300. On sweatshops and activism, both past and present: Daniel E. Bender and Richard A. Greenwald, eds. Sweatshop USA: The American Sweatshop in Historical and Global Perspective (New York, 2003).

109. Ross, Slaves, 37.

110. Lance Compa, Unfair Advantage: Workers' Freedom of Association in the United States under International Human Rights Standards (Washington, 2000); also available online at www.hrw.org/reports/2000/uslabor/ (accessed Aug. 28, 2008).

111. Ross, Slaves, 308.

112. Brian Langille, "General Reflection on the Relationship of Trade and Labor," in Bhagwati and Hudec, eds., Fair Trade, Volume 2, 238, 253.

113. French, "Wal-Mart," 39.

114. Ross, Slaves, 322. 